\title{
Lecturer Strategies in Delivering Knowledge to Students at STAIN Mandailing Natal North Sumatera
}

\author{
Kholidah Nur \\ STAIN Mandailing Natal, Indonesia
}

\begin{abstract}
Class management strategies are part of Education Management which more specifically emphasizes the ability or competence of lecturers in creating conducive learning in the classroom. This research is intended to find out how the Lecturer Strategy in Conveying Knowledge. From here, the lecturers' strategies in class will be found related to spatial planning, determining learning time, determining the source of teaching materials, creating interactions with students and creating student discipline in the classroom. This research is a field research (observation) and the data used consists of interviews, observation and documentation. The approach used in this research is qualitative. This approach is used to fully find out what strategies the lecturer has implemented in creating effective and efficient learning. By using Maslow's theory to identify a person's needs or motives in carrying out activities, while Herzberg focuses on activity satisfaction (achievement) which will motivate someone to carry out Classroom Management Effectiveness activities.
\end{abstract}

Keywords

strategy, education management; effective; efficient learning

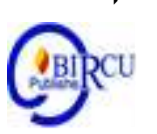

\section{Introduction}

Class management is the process of making changes in a class organization, so that individuals are willing to cooperate and develop their own controls. The role of the Lecturer encourages students to develop individual responsibility for their environment. Building student understanding so that they understand and adjust their behavior to class rules. Generates a sense of obligation to involve oneself in assignments and behavior in accordance with class activities. The strategy for compiling a learning plan is as follows: the principal through the policy set forth in the Lecturer assignment, obliges the lecturers to make teaching programs in the form of: syllabus, analysis of subject matter, annual program, semester program, and learning program plan. The making of learning programs is compiled jointly through the course lecturer meetings in the next school environment.

Professional Lecturer activities are routine lecturer activities or tasks that are considered as a way to increase their professionalism. Given the incoming input, in order to maintain and improve student academic achievement, the lecturer seeks to involve students optimally in the learning they manage.

In cooperating with students, the strategies adopted by the lecturers are as follows: First, establishing good relationships with students. Second, trying to understand the student's background. Third, mastery of the material and how to present it interestingly. Fourth, the use of various teaching models and Fifth, providing special guidance for problem students.

School development has its own meaning for this school, so that the school does not only collaborate with students, but schools also collaborate with parents/guardians, 
University lecturers, government agencies and alumni. The forms of cooperation are as follows: procurement of school facilities and facilities, recruitment of prospective students, channeling student talents and interests through extracurricular activities and procuring extracurricular coaches. Cooperation in this case, is not only carried out through classroom learning activities, but through school activities as a whole which leads to efforts to increase student learning achievement.

Teaching and learning activities are complex conditions that are intentionally created (Dimyati and Mudjiono, 2006 in Piliang and Asnewastri, 2020). Lecturers who have high motivation and not only for their own interests, will be able to carry out classroom management appropriately. The lecturer will pay attention to students and their class. Lecturers will do their best for students. In transferring subject matter to students, the lecturer will study and organize the class in such a way that it can be used to carry out the teaching and learning process properly. According to Siregar (2020) Classroom Management in the context of teaching and learning is defined as the type of activity carried out by the teacher to create and maintain optimal conditions for teaching students.

Lecturers will examine the abilities of the students one by one, so that the lecturers know the abilities of students at low, medium or high levels. Thus the lecturer will determine which students need a lot of guidance; Lecturers can determine the teaching method or learning media that should be used. The lecturer will determine how many assignments need to be assigned. What relationships do lecturers and students need, so that student learning difficulties can be overcome; student learning motivation continues to increase. Lumbantobing (2020) stated that Students who have high motivation will be seen through their actions or activities in achieving achievement or learning goals.

An indicator of an orderly class is if: First, every student continues to work, does not get stuck, meaning that there are no children who are stopped because they do not know there is a task that must be done or cannot do the task assigned to them. Second, each student continues to do work without wasting time, meaning that each student will work as quickly as possible so that he can quickly complete the assignment assigned to him.

Based on the description above, the function of class management is very basic because Lecturers' activities in managing the class include managing student behavior in the classroom, creating a socio-emotional climate and managing group processes, so that the success of lecturers in creating enabling conditions, indicators of the teaching and learning process take place effectively (Amatembun, 1989).

STAIN Madina is one of the school levels contained in the Dayah Bustanul Ulum foundation which was founded in 1961, this institution manages traditional Islamic boarding schools, in 1981 with the cooperation of the Regency Government, the Office of the Ministry of Religion and the East Aceh Ulama Council, the Ulumul Qur'an Madrasah was established, for the first time, Madrasah Ulumul Qur'an only opened education at the STAIN Madina level, only then in 1986 it was established Madrasah Aliyah.

\section{Research Methods}

This study used a descriptive analysis research method with a qualitative approach. Qualitative research as a scientific method is often used and carried out by a group of researchers in the fields of social sciences, anthropology, philosophy, religion and also the fields of education, as the author examines in this thesis. A number of reasons are also put forward, the point is that qualitative research enriches research results. Qualitative research is carried out to build knowledge through understanding and discovery. In this case the researcher collects various data and information through observation, interviews, 
documentation is presented in accordance with what is meant by information, the reasons that become the basis for doing something. Then interpreted based on the intent and reason of the perpetrator. Hersey \& Blanchard's relation to the framework of motivation and goals explains the relationship between Maslow's theory and Herzberg. Maslow identifies a person's needs or motives in carrying out activities, while Herzberg focuses on activity satisfaction (achievement) which will motivate someone to carry out Classroom Management Effectiveness activities.

\section{Discussion}

Basically, the teaching and learning process in class every 1 hour of a course is around 45 minutes, but the average lecturer meeting takes up to 2 hours so the total time is around 90 minutes. This is where STAIN lecturer Madina Ulumul Qur'an is required to be able to use time as effectively as possible so that no time is wasted.

The tendency of Lecturers at STAIN Madina that the researchers observed spent more time giving lectures or understanding to these students ranged from 30 to 40 minutes. The first 10 minutes of the lecturer opening, starting from the conditioning of the learning atmosphere, reviewing the previous lesson, then explaining the material to be discussed at this meeting. Approximately 20 minutes is usually spent doing exercises from printed books.

Although the Lecturers at STAIN Madina hold the Syllabus and RPS in which a systematic division of time has been prophesied according to the sub-discussion, in practice Lecturers have their own strategies in dividing learning time in class. This is done because it sees the condition of students that will not continue to be stable due to differences in the character and understanding of each student.

So that the Lecturer must re-evaluate every time the division of learning hours has been set in the syllabus or RPS. As the results of the interview with Ms. Junita MA, when the researcher asked about the technique of dividing study time, she answered:

"If there is a culture lesson about $45 \times 2$ minutes or as much as 90 minutes for the first 5 minutes, I usually invite students to repeat the lessons that have been passed so that they can connect to the next chapter. Then for the next 25 minutes I often give lectures to students what they don't understand, especially about culture, so I explain what the goal is, where is it going? It takes at least 25 minutes, depending on the level of difficulty, then the rest I use for discussion I organize my group to give exercises that need to be discussed there while we control the students so that for every time I usually do it like that."

Then the researcher also asked:

"Whether you ever felt less or more time when teaching in class?"

"If it is a discussion like that, students usually do not fit what we want, sometimes there is less time. while the lecture model can arrive at a predetermined time, but what we tell students sometimes quickly forgets. So if there is a shortage of time in the local area I ask them to be connected to the dormitory, because the students live in the dormitory, it is easier to monitor them."

Meanwhile, according to Mr. Asrin M.Pd, the time setting is effectively 1 hour of our lessons 45 minutes 2 hours of 90 lessons are usually used 10 minutes for the opening, one of which is reviewing yesterday's lesson or opening, just entering material for about 60 minutes and the closing is 15 minutes.

Regarding the advantages or disadvantages when teaching Mr. Asrin M.Pd stated:

"I do not feel short of hours or excess if we really set it in such a way that we briefly review the lessons we taught last week we enter the material we present the desired indicators according to the existing material because before we enter the classroom we have made a 
plan how We make existing indicators according to the time we make. If the indicators we make are too many, we don't have enough time, sometimes two or one is enough."

Meanwhile, according to Mrs. Nuraini M.Pd. he explained about how to divide the learning time as follows:

"If two hours means 90 minutes it becomes 45, 45 minutes usually for the initial perception activity, usually almost 10 minutes later, the average core activity is clear for the application of an average of 10 minutes, core activity is 60 minutes each face to face. Regarding the lack or excess of time it is the intelligence of a lecturer. When he saw that at that time the material was insufficient, the important thing was that the core of the sub-discussion had been conveyed, if at that time it was necessary to look at the condition of the students, the condition of the children in the class, the material presented."

These are some of the lecturers' opinions about their strategy in dividing learning time according to what material is explained in the class and each lecturer has a different strategy. The socio-emotional relationship between lecturers and students as well as between students also influences the learning process. You can imagine, what would happen if the lecturer did not know the students well, or the relationship between students in the class was not good. The lecturer will experience difficulties in helping students learn. This has been observed by STAIN Madina by holding trainings such as teaching talent, microteaching, workplace training organized by the North Sumatra Education and Training Center, with a point of emphasizing how the art of teaching is.

In addition, social relations between students also affect the learning process. A shy student will become even more shy if his friends always tease him whenever he makes a mistake. This situation will hamper the student learning process. This shows that the effectiveness of the learning process is not only influenced by the physical environment of the class, but also by the psycho-social environment of the class. As with the Madrasah Tsanwiyah, which notably this pesantren, between the classroom environment and the dormitory environment, it really shapes children's social relationships

Some lecturers sometimes try to build collaboration with students in learning. Building cooperation with students, meaning that in learning there is a communicative interaction between lecturers and students. These efforts: (a) establish good relationships with students through learning activities and extracurricular activities, (b) try to convey material in language that is easy for students to understand, (c) connect subject matter with everyday life, (d) use various learning models. With this strategy, the learning atmosphere becomes fun, so that students become on task in learning.

According to the deputy chairman of STAIN Madina when researchers asked about interacting with students, he stated:

The way to interact with students is as follows:

"I often provide guidance for examples of good figures to emulate, usually I give the story in historical form with 5 to 10 minutes. This really brings the child's emotional feeling closer to me as a lecturer, so that the interaction between students and lecturers can be better. From the stories of the characters and their contents, I provide guidance to them so that they can study well, obey their parents, have good morals, so that they focus on learning."

Meanwhile, according to Mr. Mukhlasan when the researcher asked about interacting with students he said that:

"Regarding interactions with children, it is clear that as a lecturer I have to interact with students in class. Then, if I'm outside the classroom, sometimes I also go to the dormitory because this is a student boarding school that lives in the dormitory so students learn Arabic with me. I use direct Arabic when speaking to students. Even though when I interacted, sometimes students didn't understand, so when they didn't understand, smart students who 
wanted to know would ask questions. Even if he doesn't ask, he looks for it first after he can ask us again so that's how I interacted in class, but outside the local dormitory I often ask questions or apply similar things."

Basically, emotional closeness or interaction between lecturers and students is very good at STAIN Madina because besides interacting on campus there is also interaction in the environment. This can happen because the pesantren system recognizes a whole or holistic education system.

All lecturers make lesson plans which include: syllabus, analysis of course materials, annual programs, semester programs, and teaching program plans. The making of teaching programs is made together with the lecturers who are members of the Course Lecturer Conference which is then confirmed at meetings of teaching devices, the arrangement of the study room and the arrangement of students in the classroom, it also needs to be prepared.

Learning resources are taken from the good syllabus prepared by the Ministry of Religion. There is already a STAIN Madina syllabus, the last one we use is the 2006 syllabus, the 2003 syllabus, and the 2008 syllabus of the Ministry of Religion standard content. So the teaching materials as well as the RPS. The minimum passing criteria are further supported by textbooks. We haven't put the textbooks donated from the Ministry of Religion to the Lecturers because, for the time being, the Lecturers hold their own books, while $70 \%$ of the students are not available, we have made certain textbooks. Sometimes learning resources are not sufficient only from the Ministry of Religion, but it is also necessary to find out through the internet library the materials we get from existing sources.

Qualified lecturers like at STAIN Madina certainly have to find as many learning resources as possible so that they have a holistic and comprehensive understanding of the material to be taught. Lecturers who are responsible and deliver material according to curriculum guidance and carry out periodic and structured evaluations. Learning sources are obtained from several aspects, namely: Books are the main source which contains learning material. This book is obtained through lecturers, libraries and other documentary studies. library, is the main media in finding learning resources for students and lecturers. Laboratory.

Being an important place for student practice in accordance with the field of study being taught. Environment The function of the environment as a learning resource is a supporting factor in complementing student knowledge which is only obtained through theoretical studies. The environment consists of:

"The learning resources I use have been given to us by the school in the form of textbooks, so textbooks are a must-have resource. This is intended so that there is a unity of understanding between Arabic language lecturers, then there are also Arabic books whose years are higher if it is related to the lessons I teach, I took it. Then to make it easier for me and the students in the teaching and learning process, apart from textbooks, I also gave LKS (Student Worksheets) and most importantly the learning resources I used relating to the environment such as parks, I immediately took them to the park, then to the library. If there are further questions there maybe we can add to the lessons that I have taught. As for the audio problem, we rarely use it because of limited tools, especially audio-visual, but it has a direction there, we just need to find the tool."

In essence, there are learning resources at STAIN Madina apart from the Ministry of Religion, so Lecturers hold their own, so the creativity of Lecturers is expected, besides that the syllabus and RPS are the main supporting capacities in improving the quality of Lecturer learning resources at STAIN Madina. 


\section{Conclusion}

Lecturers' Strategies in Managing Learning Resources in STAIN Madina Students Some of the lecturers at the STAIN Chair campus require all lecturers to make learning plans which include: syllabus, analysis of subject matter, annual programs, semester programs, and teaching program plans. Teaching programs are made together with the lecturers who are members of the course lecturers' meeting on campus. In addition to teaching equipment, the arrangement of the learning room and the arrangement of students in the classroom, it also needs to be prepared. As for additional sources of teaching materials, lecturers are given the freedom to increase their collections so that mastery of the materials will be better.

Lecturers' Strategies in Interacting with STAIN Madina Students Some of the lecturers on campus sometimes try to build cooperation with students in learning. Building cooperation with students, meaning that in learning there is a communicative interaction between lecturers and students. These efforts: establishing good relationships with students through learning activities and extracurricular activities, trying to convey material in language that is easy for students to understand, connecting subject matter with everyday life and using various learning models. With this strategy, the learning atmosphere becomes fun, so that students become ontask in learning.

\section{References}

Ahmad, R. HM. (2004). Pengelolaan Pengajaran. Jakarta: Rineka Cipta.

Amatembun, NA. (1989). Manajemen Kelas, Penuntun Bagi Guru dan Calon Guru. Bandung: FIP IKIP Bandung.

Arikunto, Suharsimi. (1996). Pengelolaan Kelas dan Siswa Sebuah Pendekatan Evaluatif. Jakarta: PT. Raja Grafindo Persada.

Buseri, H. Kamrani. (2003). Antologi Pendidikan Islam dan Dakwah; Pemikiran Teoritis Praktis Kontemporer. Yogyakarta: Universitas Islam Indonesia Press.

Danim, Sudarwan. (2002). Inovasi Pendidikan: dalam Upaya Peningkatan Profesionalsme Tenaga Kependidikan. Bandung: Pustaka Setia.

Darminta, Purwa. (1958). Kamus Umum Bahasa Indonesia. Jakarta: Dinas Penerbitan Balai Pustaka.

Dikmenum, Direktorat. (2000). Manajemen Peningkatan Mutu Berbasis Sekolah; Buku Konsep I dan Pelaksanaan MPMBS. Jakarta: Departemen Pendidikan Nasional.

Dimyati, M., Mudjiono. (1999). Belajar dan Pembelajaran. Jakarta: PT. Rineka Cipta.

Djohar, H. (2003). Pendidikan Strategik: Alternatif untuk Pendidikan Masa Depan. Yogyakarta: LESFI.

Lumbantobing, P. A. (2020). The Contribution of Lecturer Pedagogical Competence, Intellectual Intelligence and Self-Efficacy of Student Learning Motivation. Budapest International Research and Critics in Linguistics and Education (BirLE) Journal, 564573.

Piliang, F. M., Asnewastri. (2020). The Effect of Project Based Learning Model in the Group Investigation in Learning Strategy on Social Attitude Student Subject in USI Pematangsiantar. Budapest International Research and Critics Institute-Journal (BIRCI-Journal), 1599-1605.

Siregar, M. (2020). Classroom Management of Senior and Yunior English Teachers in Medan. Britain International of Humanities and Social Sciences (BIoHS) Journal, 623631. 